\title{
Tourism Typologies and Satisfaction Level of Inbound ASEAN Tourists: Perspective from Malaysia
}

\author{
Rupam Konar, Vinayaraj Mothiravally \\ School of Hospitality, Tourism and Culinary Arts \\ Taylor's University \\ Malaysia \\ Vinayaraj.Mothiravally@taylors.edu.my
}

\author{
Jeetesh Kumar \\ School of Hospitality \& Tourism \\ HELP University \\ Malaysia
}

\begin{abstract}
s
Currently, tourism industry is increasingly becoming a vital catalyst for several Associations of Southeast Asian Nations (ASEAN) for its economic development and contribution towards the countries' growth. Malaysian tourism industry is no exception to this and considered as the major source and the biggest contributor towards its economic growth. Malaysia's each tourism

offerings so that a positive perception of Malaysia's image and value can be developed to create positive influence on the ASEAN tourists' satisfaction and their loyalty towards Malaysia as destination for a diverse tourism components offering with a memorable experience contributor within the ASEAN regions countries.
\end{abstract} typologies have always something new to offer for every types of inbound tourists visiting Malaysia, with a diverse and memorable experience through their tourism components. Malaysia's ASEAN tourism market sector is the biggest tourism market when compared with the rest of the world, it has reached 27 million tourist arrival per year. With its huge number of incoming tourists, Malaysia has segmented its tourism industry in four major types of tourism to offer and those are highly regarded from the beginning of Malaysian tourism industry; explicitly as gastronomical tourism, medical tourism, leisure tourism and even business tourism have their own elite way of providing satisfying experience to every individual tourists visiting Malaysia. Current research is focusing towards assessing the factors including; socio cultural environmental impacts, tourism promotion and travel motivation, those are affecting the satisfaction level of inbound ASEAN tourists in Malaysia; thus identifying how each tourism typology moderates the satisfaction level and destination loyalty that Malaysia's different tourism typologies have to offer. A self-administered quantitative survey was used to collect the data from the tourists at the Kuala Lumpur International Airport (KLIA). A total of 320 questionnaires were distributed to the tourists at the departure hall of KLIA, where only 206 questionnaires were returned representing a response rate of $64 \%$. Judgmental sampling was used to draw the sample from the inbound ASEAN tourists for this study. A Partial Least Square based Structural Equation Modelling (PLS-SEM) approach was used in this study to assess the model; further, a multi-group moderation analysis was performed to assess the influence of tourism typologies on the satisfaction and loyalty level of the tourists. The results of the study show a significant relationship between socio cultural environmental impacts; tourism promotion; travel motivation and tourist satisfaction and further with the destination loyalty. Four highly regarded Malaysian tourism typologies moderation effect were calculated through four different model stances; indicating that Malaysian leisure tourism, medical tourism and business tourism have impressive positive influence towards the ASEAN tourists' satisfaction level and their loyalty towards Malaysia a tourism destination. Whereas, the gastronomical tourism has relative influence on the satisfaction and loyalty level of the tourists. Therefore, advisedly the Malaysian Tourism Promotion Board (MTPB) and the development of tourism Malaysia need to pay attention to develop and maintain better infrastructure and should widen the variety of gastronomical
Keywords: Tourism Typology; Travel Indicators; Tourist Satisfaction; Destination Loyalty; ASEAN; Malaysia

\section{INTRODUCTION}

Malaysia tourism sector is a big tourism market amongst all Association of Southeast Asian Nations (ASEAN) countries, as Malaysia has reached more than 25 million tourists arrival per year global inbound. With the big tourism market itself, Malaysia has many different segments in tourism industry. It can be separated into food tourism, medical tourism, cultural tourism and even business tourism has become even larger. In fact, there are not many countries offered a vast attracting points together in tourism world. With the limited amount of information available about what is behind the fast growing Malaysian tourism, this study will be conducted as a reference to know more details about factors (push and pull factors, government act, etc.) related to the growth of inbound ASEAN tourists in Malaysia. 'New political economy' that began to affect the tourism industry during the early 1990s had also influence Malaysia. In context of ASEAN countries, Malaysia is one of the countries which has a remarkable number of tourist arrival and tourist receipt. As many countries are contributor to Malaysian tourism industry, it is noticed that Malaysia's ASEAN neighboring countries are the biggest contributor until now, as for example Singapore. Singapore has hold the record of the highest number of inbound tourists to Malaysia for many years. Tourism in Malaysia is divided into many sectors that are managed by public and obviously private establishments. Both of the parties run their own business on different areas of tourism (medical, MICE, gastronomic tourism, etc.)

This paper aimed to assess the service satisfaction of inbound ASEAN tourists those have experienced different tourism services during their visit to Malaysia. In order to assess that we have used a quantitative survey based approach. Consequently, a partial least square based software namely as SmartPLS 3.2.3 used to assess the hypotheses. Further, the 
paper intended to make few important contributions in regards to suggestions for development and implications for destination marketers in different Malaysian tourism typologies; especially in field of business tourism, medical tourism and gastronomical tourism

\section{BACKGROUND OF THE STUDY}

\section{A. Tourism in Malaysia}

Plog (1987) has made a point that developing a master could protect the beauty and attractiveness of a destination, while still meeting the needs of travelers [1]. This requirement is fundamental to all groups concerned with travel and tourism, such as visitors' associations, developers, hotels, and airlines and cruise ship companies. Consequently, Malaysia has been focusing on developing many more attractions in act to attract more tourists to visit Malaysia. The pull factors for tourists, it is not enough to simply have a tourist's attraction, and government and private sector have to participate in the development of the tourism attraction. Malaysia had implemented many plans that emphasized on developing a sustainable tourism on the country. It has proven that Malaysia's main target are tourists from ASEAN neighboring countries, as Singapore to be the most contributor on tourist arrival from year to year followed by other ASEAN countries (Indonesia, Thailand and Brunei) in top 5. There are a lot of aspects that implied to the growth of tourism industry, through all of the aspects, satisfaction would be met. Satisfaction is the overall point of view from the customer by evaluating the service provided to his / her by the establishment. Other countries visitors are also attracted by the seminar and conferences together with different cultural events in Malaysia. Countries that sharing border are also tend to be positively related on demand of tourism, the other factor that supporting this is when the two countries have the same language, it is more convenient to travel to a country that has same language. Tourism promotions are also more focused on neighboring countries for example ASEAN. There are many benefits offered in Malaysia as some fellow ASEAN countries such as visa.

\section{B. SocioCultural Environmental Impact}

A high number of tourists are also categorized in high spending tourist and inbound tourists to Malaysia had a high interest in Malaysia gastronomic tourism. Since, the top inbound tourist in Malaysia is held by neighboring ASEAN countries (Singapore, Indonesia, Brunei and Thailand) than most of ASEAN tourists in Malaysia have a high expectation on having good food throughout their journey with a right price and higher quality. ASEAN tourists have a close connection with sunlust type of motivation, the lack of better amenities and several other better purposes in their own country. Like the case of medical tourism in Malaysia, the government really supported the industry and taking more and more medical tourists from other ASEAN countries, from example Indonesia. It has clarified that the medical tourism competition has become very intense [2]. Ministry of Health in Malaysia did not impose any restrictions other than advertisement guidelines. Since the establishment of the inter-ministerial
National Committee for Promotion of Medical and Health Tourism in 1998, Malaysia medical tourism has a support in the form of promotion, tax incentive, fee packaging, accreditation and packaging [3] As for the easiness of that, many ASEAN medical tourists visit Malaysia especially concentrated places like Kuala Lumpur, Penang and Melaka. Indonesian tourists would prefer to have medical treatment in Malaysia because of the price imposed is might be lower than their own local hospitals and the service provided definitely better than back in their country. Although shopping is rarely mentioned as a main reason for travelling, perhaps shopping is the most universal tourist activity and a great economic importance to local merchants. As shopping is contributing a big amount on tourists' receipts, in 2009 Shopping had contributed $28 \%$ into the total tourists' receipts.

\section{Tourism Promotion}

Malaysia has taken the right path to concentrate on neighboring ASEAN countries since they can really generate a big amount of inbound ASEAN tourist throughout years and much massive tourist receipt from year to year. As Malaysia promoting their tourism with Malaysia Truly Asia tagline, the importance of advertising and the affect it has on the Advertising must present the area to be visited as "the - place to - visit", the benefits if any, and positive images of the area, as well as and modifying the travelers' behavior, for example, purchasing the memorabilia created by the venders of the sites visited [4]. Therefore, it is a necessity, that the tourism professional use an optimal method of advertising to achieve his/her goals. An influencing promotion of tourism could use a slogan and or a logo. The motto of the logo helps clarify the visitors understanding and purpose of the agency's trip and itinerary, for example, religious, cultural, etc.[4]. By the existence of strong advertising by Malaysia, many of pull factors got published globally and many of tourists experience the actual interesting things in Malaysia. One of the strongest aspects in Malaysia tourism is food tourism.

\section{Travel Motivation}

Tourist as an individual or group itself has certain psychology pattern. Tourist will have a psychological behavior to find benefit from recreational travel and to escape from routines and stressful environment and seek for opportunities to obtain psychological rewards. Mannel and Iso-Ahola argue that people are tending to be more motivated to seek leisure or tourist activities in order to both leave behind personal or interpersonal daily life problems and obtain personal or interpersonal rewards [5]. As ASEAN countries, visiting fellow country in the same organization is not required visa and this factor is one of the pull factors for fellow ASEAN tourist to visit each other. It is agreed that travel motivation together with psychological motives (push factor) and external motives (pull factor) positively affecting tourist satisfaction. Malaysia also has made several pull factors for the tourist to visit Malaysia, as for example, allowing foreign tourist to enter by the means of visa on arrival especially for medical patient. Every tourist will have their own mindset on what to motivate and demotivate them to travel to places. There are two fundamental processes of motivation, which are wanderlust and sunlust [6]. Wanderlust can be defined as the desire to exchange the known 
for the unknown, to leave things familiar and to go and see different places, people and cultures or relics of the past in places that famous for their historical monuments and associations or for their current fashions and contributions to society. As for sunlust, a type of travel, which depends on the existence elsewhere of better amenities for a specific purpose than available in the domicile, it is prominent with particular activities such as sports and literally the search for the sun.

\section{MALAYSIAN TOURISM TYPOLOGIES}

\section{A. Business Tourism}

MICE industry is also growing really fast in Malaysia. As in fact, MICE sector qualified as one of the fastest growing industry worldwide. In addition, MICE sector also generate direct and indirect income for a country [7]. It consists of many different components, including: exhibitions, incentive, meeting, trade show, seminar, conventions and conferences. All of its activities requires many cooperation with other players, for the likes of transport (international or domestic), accommodation, pre and post event touring, audiovisual services, convention centers, or exhibition facilities [8]. Kuala Lumpur is one of the strongest business tourism destinations other than Bangkok and Jakarta. MICE (Meeting, Incentive, Convention and Exhibition) sector consists of related forms of meetings, incentives, conventions and exhibitions activities altogether with conferences, congresses and trade show. This sector has been taken as one of the most dynamic and important sector of the tourism industry that focuses on business activities rather than leisure [9]. MICE market in Malaysia had contributed $30 \%$ of total tourism sector revenue. The contribution occurred when a group of business traveler visit Malaysia and spend money on an incentive trip. Business traveler spends 3 to 5 times higher than a normal leisure traveler on average. In terms of ASEAN, Malaysia is one of the strongest MICE market holders, even they are in the 7 th in Asia Pacific ranking. Especially, Kuala Lumpur is one of the strongest and facilitated cities to hold MICE event.

\section{B. Medical Tourism}

Medical tourism is travelling activity of patients from one (the "home") country to another (the "destination") country for medical treatment [10]. Medical tourism or medical travel is the act of travelling to other countries to obtain medical, dental, and surgical care. Reasons pushing medical travel include lower healthcare costs as well as the search of expert in medical treatments, waiting times, safety and quality of care. Malaysia is one of the famous medical destination worldwide, amongst Brunei, Cuba, Colombia, Hong Kong, Hungary, India, Israel, Jordan, Lithuania, Philippines, Singapore and Thailand. Malaysia has received about 698,000 medical tourists on 2012. The Ministry of Health stated that Malaysia had generated US\$ 101.65 million from medical tourism sector in 2010 and it is expected to grow to about US\$ 116.5 million in 2011. Neighboring ASEAN countries are also the biggest contributors into this segment of tourism. It was recorded that Singapore $(72 \%)$ holds the highest place for medical tourists' contributor and followed by Indonesia (10\%). The majority of the patient will go to Penang (61\%), Malacca and Kuala
Lumpur hold 19\% and 11\% respectively [11]. Ormond (2011) had also discovered that Indonesians has consideration about Malaysia medical tourism is within reach physically and economically than the national alternative which requires a flight to Jakarta with total costs equal to or greater than in Malaysia, Penang and Malacca provide healthcare services critical for the Indonesian island of Sumatra [11].

\section{Gastronimic Tourism}

Culinary, gastronomic or gourmet tourism is really closed definition for food tourism [12, 13], which Food tourism is known as travelling to certain food events or visiting a particular restaurant for the traveler to experience the dishes offered [12]. In 2002, Malaysia was in the top fifteen countries in the world to visit by WTO. According to Bessiere [14]; Hall and Sharples [12] Long [13], nowadays tourists are travelling with a mean of finding and experience different kind of food that is a signature of the destination and as a result, food tourism in a wide point of view globally has become as a pull factor in destination marketing. Furthermore, the Ninth Malaysia Plan (2006-2010) has planned for innovative food differentiation based on the specialties of states, regions and communities to attract tourist to enjoy local delicacies. The states of Melaka, Penang, Perak, Sarawak and Sabah could be highlighted as "the states for gastronomy routes". Specific information about Malaysia's culinary offerings is important [15]. Since food can provide a more enjoyable holiday atmosphere and is unmistakably a plus for the tourism industry. Hence, with such an exciting diversity of food, Malaysia should be taken as the destination to enjoy the art of gastronomy. Malaysian gastronomy should be considered important when promoting local destinations. Malaysian cuisine is being introduced to the globally, which represents a mix of Chinese, Malay and Indian cooking through the "Malaysia Kitchen", simultaneously helping to establish side industries like the production of spices for the dishes.

\section{Tourism Satisafaction and Loyalty}

Bigne et al. (2001) defined a revisit activity of a tourist is the outcome of the satisfaction level experienced during the visit [15]. Satisfaction model is the most well-known structure to conclude the revisit intention of a tourist. Satisfaction exist when the initial expectation is beaten by the actual condition. On the contrary, Parasuraman (1990) indicated that if performance underrated requirements, it would create dissatisfaction on a person, which will cause further disappointment. From tourist point of view, it will bring the same concept because they are subscribers to the services provided by the tourist destination [16]. Other influencing factors could be in the matter of number of previous visit [17, $18]$ or quality related experienced during the last visit [19, 20, $21,22]$. Immigration of Malaysia had publicized that $72.8 \%$ inbound tourist to Malaysia are from ASEAN neighboring countries, which are Singapore, Thailand, Indonesia and Brunei Darussalam. It is more cost efficient to retain a revisiting traveler rather than influenced new traveler visit a country. There are many factor affecting the satisfaction level of a tourist in travelling activities. Tourist attraction in the destination, beauty of the landscape, culture and hospitality services provided by the hotel staffs, quality of the food and 
beverages served and even the friendliness of local citizens are some of the factors that are really giving an impact on the overall tourist satisfaction. Malaysia has more amusement facilities compared to others, cheap and various accommodations and tour packages, health and hygiene tourism attractions and also varieties religions live together peacefully. If the performance cannot match visitor's expectation, it can be predicted they will not give a second visit. Satisfaction is one of the most important things for customer's mental state, whether they will decide to visit again or not. In tourism field it is often said as travel satisfaction, which is the level of satisfaction of a tourist gained throughout services that they experienced during the time of visit [23].

\section{HYPOTHESIS DEVELOPMENT}

In order to achieve the aim and objectives four hypotheses are being developed in order to understand the tourists' level of satisfaction with tourism services across three major tourism typologies. The four hypotheses are as follows;

H1. Socio cultural environmental impact is positively related to tourist satisfaction with services among all tourism typologies.

H2. Tourism promotion is positively related to tourist satisfaction with services among all tourism typologies.

H3. Travel motivation is positively related to tourist satisfaction with services among all tourism typologies.

H4. Tourist satisfaction with services is positively related to destination loyalty among all tourism typologies.

\section{RESEARCH METHODOLOGY}

\section{A. Research Instrument}

To measure the different tourism typologies effect size on the inbound Asian tourists' satisfaction level; factors such as socio cultural environmental impacts, tourism promotion and travel motivation were found to be the most appropriate measures. Tourist satisfaction with services was measured using three items [17]; These variables were measured using a five-point Likert scale starting from 1 (strongly disagree) to 5 (strongly agree).

\section{B. Sampling and Data Colelction}

The primary target population for this current study was limited to those tourists are coming from ASEAN region and had stayed in Malaysia during their visit purpose. The data for this study was being collected through face-to-face interaction with the tourist at the Kuala Lumpur International Airport 2 (KLIA2) at the departure hall after taking the permission from the airport authority. The KLIA2 was selected due large pool of inbound and outbound ASEAN tourist travelling in Malaysia using low cost carrier airlines. A self-administered survey was being used for this study through a non-probability judgmental sampling technique. The sample size for this study was collected over three weeks through a distribution of 320 questionnaires at different times of the day. In order to reduce biasness, the survey instrument was being explained to the outbound tourists along with its purpose. A total accumulated number 206 questionnaires were found to be usable for this study and further used for data analysis. Out of 206 respondents, $55.3 \%$ were males and $44.7 \%$ were males. Majority of them aged between $16-25$ years $(61.2 \%)$ followed by $26-35$ years $(19.4 \%$ ) and $14.6 \%$ were aged between $36-45$ years. There was mix between the respondents but it was found $55.3 \%$ (114) respondents were from Indonesia followed by $14.6 \%$ were from Singapore and $7.8 \%$ were from Thailand.

\section{FINDINGS AND ANALYSIS}

The collected data was analyzed using SPSS Statistics v23 and SmartPLS-SEM (Partial Least Square) 3.2.3. As suggested by Hair et al. (2013) [24] and Ringle et al. (2005)[25] to measure the model PLS algorithm and bootstrapping method were used to measure the measurement model and structural model. The measurement model was assessed for convergent validity.

\section{A. Measuurement Model}

Through analyzing factor loadings, composite reliability (CR) and average variance extracted (AVE) (Hair et al., 2006) the measurement model was analyzed in Table 1, which shows all the item loadings have exceeded the recommendation value of 0.6 (Chin, 1998).

\begin{tabular}{|c|c|c|}
\hline \multicolumn{2}{|r|}{ Items } & $\begin{array}{c}\text { Loadin } \\
\text { gs }\end{array}$ \\
\hline \multicolumn{3}{|c|}{$\begin{array}{c}\text { Socio Cultural Environmental Impact }\left(\mathrm{AVE}^{\mathrm{b}}=0.545\right. \\
\left.\text { Composite Reliability }^{\mathrm{a}}=0.878\right)\end{array}$} \\
\hline SCEI1 & $\begin{array}{l}\text { Malaysia as a country always creates } \\
\text { favorite image to me }\end{array}$ & 0.693 \\
\hline SCEI2 & $\begin{array}{l}\text { Malaysia facilities in process of different } \\
\text { modernization in tourism services }\end{array}$ & 0.733 \\
\hline SCEI3 & $\begin{array}{c}\text { Malaysia's different tourism encourages } \\
\text { pride in local arts, crafts, and cultural } \\
\text { expressions }\end{array}$ & 0.662 \\
\hline SCEI4 & $\begin{array}{c}\text { Offered tourism in Malaysia satisfies my } \\
\text { visit experiences }\end{array}$ & 0.779 \\
\hline SCEI5 & $\begin{array}{l}\text { Malaysian tourism encourages } \\
\text { environmental protection }\end{array}$ & 0.777 \\
\hline SCEI6 & $\begin{array}{l}\text { Malaysian tourism promotes } \\
\text { environmental value based tourism }\end{array}$ & 0.778 \\
\hline \multicolumn{3}{|c|}{ 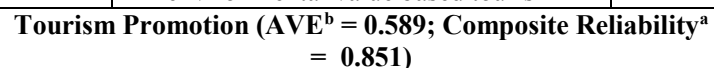 } \\
\hline TP1 & $\begin{array}{c}\text { I found tourism services in Malaysia as } \\
\text { same as it is being promoted in my } \\
\text { country }\end{array}$ & 0.802 \\
\hline TP2 & $\begin{array}{l}\text { Malaysia do promote their different } \\
\text { types of tourism products and services in } \\
\text { my country }\end{array}$ & 0.763 \\
\hline TP3 & $\begin{array}{l}\text { I get information regarding different } \\
\text { tourism products and services offered by } \\
\text { Malaysia easily in my country }\end{array}$ & 0.772 \\
\hline TP4 & $\begin{array}{l}\text { Malaysian tourism promotions have } \\
\text { always something new to offer every } \\
\text { time }\end{array}$ & 0.730 \\
\hline \multicolumn{3}{|c|}{$\begin{array}{c}\text { Travel Motivation }\left(\mathrm{AVE}^{\mathrm{b}}=0.508 ; \text { Composite Reliability }^{\mathrm{a}}=\right. \\
\mathbf{0 . 8 5 2})\end{array}$} \\
\hline TM1 & $\begin{array}{l}\text { I find mental relaxation when I am } \\
\text { travelling to Malaysia }\end{array}$ & 0.729 \\
\hline TM2 & $\begin{array}{c}\text { Different tourism products and services } \\
\text { offered here always motivates me to } \\
\text { travel to Malaysia }\end{array}$ & 0.695 \\
\hline TM3 & I travel to Malaysia for a change of pace & 0.673 \\
\hline
\end{tabular}




\begin{tabular}{|c|c|c|}
\hline & from everyday life & \\
\hline TM4 & $\begin{array}{l}\text { I travel to Malaysia to gain a sense of } \\
\text { accomplishment }\end{array}$ & 0.680 \\
\hline TM5 & $\begin{array}{l}\text { I enjoy travelling to Malaysia, which } \\
\text { helps me to meet new people }\end{array}$ & 0.711 \\
\hline TM6 & $\begin{array}{l}\text { Malaysia's tourism offerings are always } \\
\text { new which motivates me to travel }\end{array}$ & 0.704 \\
\hline \multicolumn{3}{|c|}{$\begin{array}{c}\text { Tourist Satisfaction with Services }\left(\mathrm{AVE}^{\mathrm{b}}=0.538 ;\right. \\
\left.\text { Composite Reliability }^{\mathrm{a}}=\mathbf{0 . 7 9 4}\right)\end{array}$} \\
\hline TSS1 & $\begin{array}{c}\text { I am satisfied with Malaysian tourism's } \\
\text { social, cultural and environmental } \\
\text { offerings }\end{array}$ & 0.756 \\
\hline TSS2 & $\begin{array}{l}\text { I think I made a wise decision to visit } \\
\text { Malaysia for purpose }\end{array}$ & 0.728 \\
\hline TSS3 & $\begin{array}{l}\text { I believe Malaysian tourism offerings } \\
\text { have good reputation in my country }\end{array}$ & 0.699 \\
\hline TSS4 & $\begin{array}{c}\text { I am satisfied with the tourism products } \\
\text { and services offered to me during my } \\
\text { visit }\end{array}$ & 0686 \\
\hline \multicolumn{3}{|c|}{ 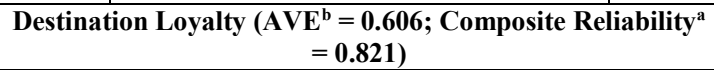 } \\
\hline DL1 & $\begin{array}{l}\text { I would like to visit Malaysia in near } \\
\text { future }\end{array}$ & 0.755 \\
\hline DL2 & $\begin{array}{l}\text { I would like to experience Malaysian } \\
\text { tourism offering in future }\end{array}$ & 0.734 \\
\hline DL3 & $\begin{array}{l}\text { I would recommend my friend and } \\
\text { families to visit Malaysia }\end{array}$ & 0.715 \\
\hline DL4 & $\begin{array}{l}\text { I consider Malaysia as one of my } \\
\text { favorite destination to visit }\end{array}$ & 0.699 \\
\hline \multicolumn{3}{|c|}{$\begin{array}{c}{ }^{a} \text { Composite reliability = (square of the summation of the factor } \\
\text { loadings) / [(square of the summation of the factor loadings) }+ \\
\text { (square of the summation of the error variances)] } \\
{ }^{b} A V E=\text { (summation of squared factor loadings)/(summation of } \\
\text { squared factor loadings) (summation of error variances) }\end{array}$} \\
\hline
\end{tabular}

Further, composite reliability values those represent to what point the construct indicators indicate the latent construct, exceeds the recommended value of 0.7 [24] and the values of average variance extracted also exceeded the recommendation value of 0.5 [24] reflecting the overall degree of variance explained by the latent constructs.

Consequently, the next step was to assess the discriminant validity, refereeing to 'the extent to which the measures are not a reflection of some other variables' instead its indicated by the low correlation between measures [26]. The Table 2 below shows the square root of the AVE (diagonal values) of individual construct, larger than its corresponding correlation coefficients indicating an adequate discriminant validity [27]. Finally, the measurement model shows a satisfactory level of convergent validity and discriminant validity.

\begin{tabular}{|c|c|c|c|c|c|}
\hline & SCEI & TP & TM & TSS & DL \\
\hline SCEI & $\mathbf{0 . 7 3 8 *}$ & & & & \\
\hline TP & 0.599 & $\mathbf{0 . 7 6 7 *}$ & & & \\
\hline TM & 0.500 & 0.617 & $\mathbf{0 . 7 1 7 *}$ & & \\
\hline TSS & 0.534 & 0.705 & 0.636 & $\mathbf{0 . 6 9 9 *}$ & \\
\hline DL & 0.701 & 0.724 & 0.693 & 0.633 & $\mathbf{0 . 7 2 6 *}$ \\
\hline Note. * Square root (AVE) on the diagonal in boldface and \\
construct correlations below the diagonal. \\
SCEI= Socio Cultural Environmental Impact, TP= Tourism \\
Promotion, TM= Travel Motivation, TSS= Tourist Satisfaction \\
with Services, DL= Destination Loyalty
\end{tabular}

\section{B. Complete Structural Model}

A bootstrapping method was used to assess the structural model and hypotheses through SmartPLS 3.2.3 [26]. A 5000 iterations bootstrapping procedure was performed to examine the weightage of predictors with 206 cases were being used for the measurement of the coefficient paths [28, 24]. Further, these coefficients paths were assessed according to the critical values of t-statistics; as referred by Hair etal.[24] in social science studies the path coefficients critical values of tstatistics as 1.96 (significance level 5\%) and 2.57 (significance level $1 \%$ ). With the aim of this research paper is to measure the effect of three predictors on tourist satisfaction across different

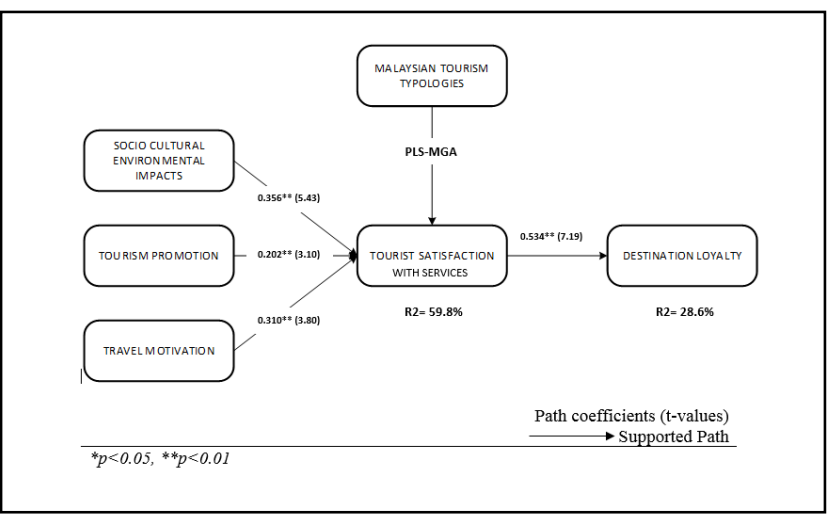

tourism typologies a multi-group analysis (PLS-MGA) was performed to assess the path co-efficient variances for three different stances [29]; namely under business tourism, gastronomic tourism and medical tourism. In order to proceed with PLS-MGA the whole structural model have to tested with the entire sample size of the study the Figure 1 has been illustrated to demonstrate the path coefficients values based on entire sample size of this study. Additionally, in the further analysis of structural model, the hypotheses were tested with the corrected R2 values and path coefficients values including t-statistics values of the predictor variables. At the initial level tourist satisfaction with services level as an endogenous variable being explained 59.8\% $\quad\left(\mathrm{R}^{2}=0.598\right)$ by three exogenous variables namely as; socio cultural environmental impact, tourism promotion, travel motivation; consequently, at the second level tourist satisfaction with services as an exogenous variable predicted destination loyalty by $28.6 \%$ $\left(\mathrm{R}^{2}=0.286\right)$.

Fig. 1. Results of Complete Structural Model (n=206)

\section{Partical Least based Multi Group Analysis (PLS-MGA)}

Generally, through PLS modelling approach the test between two groups are common using the same parameters. As soon as if there are more parameters, similar to this current research where we have analyzed the satisfaction with services in respect to three different tourisms (medical tourism, gastronomical tourism and business tourism) stances; the one question arises; does the parameter differs from group to group? In order two address that we have conducted PLS based multi group analysis (MGA) [29, 30]. The Table 3 below has been illustrated in more specific mode in order to facilitate the understanding of the analysis output. Hence, PLS path analysis model reveals that the model has met the criteria as suggested 
by Chin (1998) [28], and Hair et al. (2012) [24]. Subsequently, the analyses for different tourism typologies show that all the predictor variables' composite reliability are above 0.708 followed by average variance extracted (AVE) above 0.50 .

We proceeded further after assessing the constructs discriminant validity and convergent validity analyses applying criterion set by Fornell and Larcker (1981) [27]. The Table 3 shows the results of structural model assessment. A bootstrapping of 5,000 sample and the cases were based on the sample size specific to type of tourists'. In three different typologies of tourism the three predictors (SCEI, TP, TM) have achieved the R2 value $68.8 \%(0.688)$ in medical tourism, $53.2 \%(0.532)$ in gastronomical tourism and $64.4 \%(0.644)$ in business tourism; thus reflecting the predictability of independent variables towards the depending variable. Consequently, showing that medical tourists satisfaction with services are significant $(p<\max .0 .01$ and min. 0.05) among the four different hypotheses. Further, in gastronomical tourism subsample among the four hypotheses three hypotheses $(\mathrm{H} 1$, $\mathrm{H} 3, \mathrm{H} 4)$ found to be highly significant $(p<0.01)$ whereas H2 found to be non-significant referring to 'tourism promotion' have no impact on tourist satisfaction. In business tourism consequence, it was found similar to the results of gastronomical tourism; where nearly three of the hypotheses $(\mathrm{H} 1, \mathrm{H} 3, \mathrm{H} 4)$ managed to achieve high significance level $(p<$ $0.1 ., 0.01$ ) and $\mathrm{H} 2$ found to be non-significant in relation to tourism promotion towards tourists' satisfaction with services.

\begin{tabular}{|c|c|c|c|c|c|}
\hline & & & $\begin{array}{l}\text { Medical } \\
\text { Tourism } \\
\end{array}$ & $\begin{array}{c}\text { Gastronomic } \\
\text { Tourism }\end{array}$ & $\begin{array}{l}\text { Business } \\
\text { Tourism } \\
\end{array}$ \\
\hline & $\begin{array}{c}\text { Latent } \\
\text { Variabl } \\
\text { es }\end{array}$ & & & & \\
\hline & SCEI & $\begin{array}{c}\text { Composite } \\
\text { Reliability } \\
\text { AVE }\end{array}$ & $\begin{array}{l}0.894 \\
0.587\end{array}$ & $\begin{array}{l}0.880 \\
0.551\end{array}$ & $\begin{array}{l}0.849 \\
0.593\end{array}$ \\
\hline & TP & $\begin{array}{c}\text { Composite } \\
\text { Reliability } \\
\text { AVE } \\
\end{array}$ & $\begin{array}{l}0.861 \\
0.608\end{array}$ & $\begin{array}{l}0.865 \\
0.551\end{array}$ & $\begin{array}{l}0.865 \\
0.616\end{array}$ \\
\hline & $\mathrm{TM}$ & $\begin{array}{c}\text { Composite } \\
\text { Reliability } \\
\text { AVE }\end{array}$ & $\begin{array}{l}0.878 \\
0.547\end{array}$ & $\begin{array}{l}0.811 \\
0.521\end{array}$ & $\begin{array}{l}0.855 \\
0.598\end{array}$ \\
\hline & TSS & $\begin{array}{c}\text { Composite } \\
\text { Reliability } \\
\text { AVE }\end{array}$ & $\begin{array}{l}0.806 \\
0.510\end{array}$ & $\begin{array}{l}0.771 \\
0.558\end{array}$ & $\begin{array}{l}0.844 \\
0.575\end{array}$ \\
\hline & DL & $\begin{array}{c}\text { Composite } \\
\text { Reliability } \\
\text { AVE }\end{array}$ & $\begin{array}{l}0.814 \\
0.524\end{array}$ & $\begin{array}{l}0.793 \\
0.590\end{array}$ & $\begin{array}{l}0.840 \\
0.568\end{array}$ \\
\hline $\begin{array}{c}\text { Sample } \\
(\mathrm{n})\end{array}$ & & & 78 & 69 & 59 \\
\hline $\begin{array}{c}\text { Hypothese } \\
s\end{array}$ & $\begin{array}{c}\text { Path } \\
\text { Relations } \\
\text { hips }\end{array}$ & & & & \\
\hline H1 & $\begin{array}{l}\text { SCEI - } \\
>\text { TSS }\end{array}$ & $\begin{array}{c}\text { Path } \\
\text { Coefficient } \\
\text { s } \\
\text { t- values }\end{array}$ & $\begin{array}{l}0.444 * \\
* \\
5.63\end{array}$ & $\begin{array}{l}0.391 * * \\
2.91\end{array}$ & $\begin{array}{l}0.217^{*} \\
1.72\end{array}$ \\
\hline H2 & $\begin{array}{c}\text { TP }-> \\
\text { TSS }\end{array}$ & $\begin{array}{c}\text { Path } \\
\text { Coefficient } \\
\text { s } \\
\text { t- values }\end{array}$ & $\begin{array}{l}0.306^{*} \\
* \\
3.69\end{array}$ & $\begin{array}{l}0.008 \\
0.07\end{array}$ & $\begin{array}{l}0.184 \\
1.14\end{array}$ \\
\hline H3 & $\begin{array}{c}\text { TM -> } \\
\text { TSS }\end{array}$ & $\begin{array}{c}\text { Path } \\
\text { Coefficient } \\
\text { s } \\
\text { t- values }\end{array}$ & $\begin{array}{l}0.202^{*} \\
1.81\end{array}$ & $\begin{array}{l}0.393^{* * *} \\
2.73\end{array}$ & $\begin{array}{l}0.470 * \\
* \\
3.39\end{array}$ \\
\hline
\end{tabular}

\begin{tabular}{|c|c|c|c|c|c|}
\hline H4 & $\begin{array}{c}\mathrm{TSS}-> \\
\mathrm{DL}\end{array}$ & $\begin{array}{c}\text { Path } \\
\text { Coefficient } \\
\text { s } \\
\text { t- values }\end{array}$ & $\begin{array}{l}0.656^{*} \\
* \\
5.95\end{array}$ & $\begin{array}{l}0.562 * * \\
6.43\end{array}$ & $\begin{array}{l}0.440 * \\
* \\
2.92\end{array}$ \\
\hline & $R^{2}$ & & & & \\
\hline & TSS & & 0.688 & 0.532 & 0.644 \\
\hline & DL & & 0.430 & 0.316 & 0.194 \\
\hline \multicolumn{6}{|c|}{$\begin{array}{l}\text { Notes: } \\
\text { AVE }=\text { Average Variance Extracted } \\
\text { nificance at } 0.05 \text {, **significance at } 0.01 . \\
\text { o Cultural Environmental Impact, } T P=\text { Tourism } \\
=\text { Travel Motivation, TSS = Tourist Satisfaction with } \\
\text { Services, } D L=\text { Destination Loyalty }\end{array}$} \\
\hline
\end{tabular}

\section{CONCLUSION \& IMPLICATIONS}

This study aimed to identify the level of satisfaction and destination loyalty of ASEAN tourists visiting Malaysia for different tourism purposes and majorly for medical tourism, gastronomical tourism and business tourism. The satisfaction level based on different tourism typologies with their services have received much attention within the researchers as well as among different country specific tourism service management authorities [31, 32]. However fewer studies have focused on identifying satisfaction with services across tourism typologies [33]. The results from this study reveals that several tourism typologies offered by Malaysia have different level of satisfaction towards its tourists' base. The major variables for this study, such as; socio cultural environmental impacts, tourism promotion and tourist motivation were considered due to hedonic nature of tourist experiences pre and post of their travel. Beginning from choosing Malaysia due its tourism promotions and further intended pre-travel motivation towards visiting and lastly experiencing Malaysia's socio-economiccultural phenomena in their travel days; overall creating the hedonic experience this experience level found to be satisfactory based on the output of our study across three different tourisms; medical tourism, gastronomical tourism and business tourism. The study fills the gap by investigating the service satisfaction of Malaysian tourism typologies towards inbound ASEAN tourists. According to the output of results, the major importance should be given in to promote the gastronomical tourism and business tourism across the ASEAN countries to attract more tourists to Malaysia by the destination marketers; which found to be similar studies conducted by Henderson (2008)[34]. In terms of revisiting Malaysia, the results indicate that affordable medical tourism attracts the ASEAN tourists for the second time while comparing to others it has higher relationship value between satisfaction and destination loyalty among the tourist. Where is in business tourism the tourists' destination loyalty found to be the lowest comparing to others.

Consequently, from a pragmatic point of view the results offer important implications for Malaysian destination marketers in order to fine tune different strategies towards the development of different service offerings. The findings suggest the existence of tourist satisfaction level differences with different typologies of tourism offered by Malaysia. Identifying these differences provides various opportunities for destinations to shape their marketing techniques to influence the revisit intentions within the ASEAN tourists travel 
behavior. As from the results we have identified tourism promotion for gastronomical and business tourism resulted a non-significant relationship resulting a low satisfaction level among the inbound ASEAN tourists. For different destination marketers should make additional efforts to understand what causes these low satisfaction levels for these types of tourism promotional efforts towards the ASEAN tourists. The destination marketers should review the mix of activities offered for different tourism typologies within the destination. The Malaysian Tourism Promotion Board (MTPB) should be more attentive towards developing better infrastructure and should widen the variety of business possibilities and gastronomical offerings so that a positive perception of Malaysia's image and value can be developed. Therefore, creating a positive influence on the ASEAN tourists' satisfaction and their loyalty towards Malaysia as destination for a diverse tourism components offering and as a memorable experience contributor within the ASEAN region countries

\section{REFERENCES}

[1] Plog, S. C. (1972). Why Destination Area Rise and Fall in Popularity. Paper presented to the Travel Research Association Southern California Chapter, Los Angeles, October.

[2] Herberholz, C., and Supakankunti, S. (n.d.). Medical Tourism in Malaysia, Singapore and Thailand.

[3] Chee, H. L. "Ownership, Control, and Contention: Challenges for the Future of Healthcare in Malaysia." Social Science \& Medicine66 (2008): 2145-2156.

[4] Salehi, H., and Farahbakhsh, M. (2014). Tourism Advertisement Management and Effective Tools in Tourism Industry. Sarmidi, T., \& Salleh, N. H. (2010). Dynamic Inter-Relationship between Trade, Economic Growth and Tourism in Malaysia.Pusat Pengajian Ekonomi, Fakulti Ekonomi dan Perniagaan, 1-13.

[5] Mannel, R. C., and Iso-Ahola, S. E. (1987) Psychological Nature of Leisure and Tourism Experience. Annals of Tourism Research 14(3), 314-33.

[6] Gray, H. P. (1970). International Travel - International Trade. Lexington: Heath Lexington Books.

[7] Lawrence, M., and McCabe, V. (2001). Managing Conferences in Regional Areas: A Practical Evaluation in Conference Management. International Journal of Contemporary Hospitality Management, 13(4/5), 204-208.

[8] Dwyer, L., Mistilis, N., Forsyth, P., and Rao, P. (2001). International Price Competitiveness of Australia's MICE Industry. International Journal of Tourism Research, 3, 123.

[9] McCabe, V., Poole, B., Weeks, P., and Leiper, N. (2000). The Business and Management of Conventions. Brisbane: Wiley Australia Baker, DA, Crompton JL. (2000). Quality, satisfaction and behavioural intentions. Annals of Tourism Research. 27(3): 785-804.

[10] Cohen, G. (2011). Medical Tourism, Access to, 1(1). Retrieved from www.vjil.org.

[11] Ormond, Meghann. (2011) Medical Tourism, Medical Exile: Responding to the Cross-Border Pursuit of Healthcare in Malaysia. In Minca, C. and Oakes, T. (eds), Real Tourism: Practice, Care and Politics in Contemporary Travel, London: Routledge.

[12] Hall, M., and Sharples, L. (2003). The Consumption of Experiences or the Experience of Consumption? An Introduction to the Tourism of Taste. In M. Hall, L. Sharples, R. Mitchell, N. Macionis, \& B. Cambourne (Eds.), Food Tourism around the World: Development, Management and Markets. Oxford: Butterworth-Heinemann.

[13] Long, L. M. (2004). Culinary Tourism: A Folkloristic on Eating and Otherness. In L. M. Long, (Ed.), Culinary Tourism (pp. 20-50). Lexington, K.Y.: The University Press of Kentucky.
[14] Bessiere, J. (1998). Local Development and Heritage: Traditional Food and Cuisine as Tourist Attractions in Rural Areas. Sociologia Ruralis, 38 (1), 21-34.

[15] Shahrim, M., Chua, B. L., and Hamdin, S. (2010). Malaysia as a Culinary Tourism Destination: International Tourist ${ }^{\text {ee }} \mathrm{s}$ Perspective. Journal of Tourism, Hospitaly and Culinary Arts, 1(3)

[16] Bigne, J. E., Sanchez, M. I., and Sanchez, J. (2001). Tourism Image, Evaluation Variables and After Purchase Behavior: Inter-Relationship. Tourism Management, 22 (6), 607-616. dx.doi.org/10.1016/S0261-5177 (01)00035-8

[17] Parasuraman, A., Zeithaml, V. and Berry, L. (1990). Delivering Quality Service. New York, Free Press.

[18] Kozak, M. (2001). Repeaters' behavior at two distinct destinations. Annals of Tourism Research, 28(3), 784-807.

[19] Petrick, J. F., Morais, D. D., and Norman, W. C. (2001). An Examination of the Determinants of Entertainment Vacationers' Intentions to Revisit. Journal of Travel Research, 40 (1), 41-48. dx.doi.org/

[20] Chen, J. S., and Gursoy, D. (2001). An Investigation of Tourists Destination Loyalty and Preferences. International Journal of Contemporary Hospitality Management, 13 (2), 79-85. dx.doi.org/10.1108/09596110110381870

[21] Zainal, A., Ahmad Zali, N., and Kassim, M, N. (2010). Malaysian Gastronomy Routes as a Tourist Destination. Journal of Tourism, Hospitaly and Culinary Arts, Vol: 2, Issue 1.

[22] Frochot, I., and Hughes, H. (2000). HISTOQUAL: The Development of a Historic Houses Assessment Scale. Tourism management, 21(2), $157-$ 167.

[23] Baker, D.A., Crompton J.L. (2000). Quality, Satisfaction and Behavioral Intentions, Annals of Tourism Research, 27(3): 785-804.

[24] Gundersen, M. G., Heide, M., dan Olsson, U. H. (1996). Hotel Guest Satisfaction Among Business Travelers - What Are The Important Factors? Cornell Hotel and Restaurant Administration Quarterly, April, Volume 36 (2), 72-81

[25] Hair, J. F., Black, W. C., Babin, B. J., Anderson, R. E., \& Tatham, R. L. (2006). Multivariate data analysis (6th ed.). Upper Saddle River, NJ: Prentice-Hall.

[26] Ringle, C., Wende, S., \& Will, A. (2005). SmartPLS 2.0 (Beta). Hamburg, (www.smartpls.de).

[27] Ramayah, T., Yeap, J.A.L. and Igatius, J. (2013). An empirical inquiry on knowledge sharing among academicians in higher learning institutions. Minerva, 51(2), 131-154.

[28] Fornell, C. G., \& Larcker, D. F. (1981). Evaluating structural equation models with unobservable variables and measurement error. Journal of Marketing Research, 18(1), 39-50.

[29] Chin, W. W., \& Dibbern, J. (2010). Handbook of Partial Least Squares. Berlin, Heidelberg: Springer http://doi.org/10.1007/978-3-540-32827-8

[30] Sarstedt, M.B., Jan., M., Ringle, C.M., Schwaiger, M. (2011). Uncovering and treating unobserved heterogeneity with FIMIX-PLS: which model selection criterion provides an appropriate number of segments? Schmalenbach Business Review 63(1), 34-62.

[31] Hoffmann, S., Mai, R., \& Smirnova, M. (2011). Development and validation of a crossnationally stable scale of consumer animosity. Journal of Marketing Theory and Practice, 19(2), 235-251.

[32] Ng, D., \& Konar, R. (2015). Determinants of Travel Motivation: A PLSSEM Approach Towards Maldivians Traveling Overseas. In 21st Asia Pacific Tourism Association Annual Conference (pp. 426-437). Kuala Lumpur.

[33] Song, H., \& Cheung, C. (2010). Attributes affecting the level of tourist satisfaction with and loyalty towards theatrical performance in China: Henderson, J. (2008). Tourism Destination Development: The Case of Malaysia. Tourism Recreation Research, 33(1), 49-57. http://dx.doi.org/10.1080/02508281.2008.11081289

[34] Hosany, S., \& Prayag, G. (2013). Patterns of tourists' emotional responses, satisfaction, and intention to recommend. Journal of Business $\begin{array}{lll}\text { Research, } & 66(6), & \text { 730-737. }\end{array}$ http://dx.doi.org/10.1016/j.jbusres.2011.09.011 
Asia Tourism Forum 2016 - The 12th Biennial Conference of Hospitality and Tourism Industry in Asia (ATF-16)

[35] Henderson, j. (2008) Tourism Destination Development: The Case of Malaysia. Tourism Recreation Research, 33(1), 49-57. 